\title{
EXPLORING STUDENTS' SATISFACTION WITH AN ACADEMIC PROGRAM. THE CASE OF BUSINESS INFORMATION SYSTEMS SPECIALIZATION
}

\author{
Doina DĂNĂIAṬ̂A \\ West University of Timişoara, Romania \\ doina.danaiata@e-uvt.ro \\ Vasile Daniel PĂVĂLOAIA \\ Al. I. Cuza University of Iaşi, Romania \\ danpav@uaic.ro \\ Luminița HURBEAN \\ West University of Timișoara, Romania \\ luminita.hurbean@e-uvt.ro
}

Doina FOTACHE

Al. I. Cuza University of Iaşi, Romania doina.fotache@uaic.ro

\begin{abstract}
Considering the competitive academic environment, factors that determine students' satisfaction with their chosen specialization should be studied to determine how well an academic program meets students' expectancies. Our study attempts to investigate the underlying factors behind the satisfaction of third-year students in the same bachelor program (Business Information Systems) in two Romanian universities. These satisfaction factors are then analyzed in correlation with the respondents' future desire to continue their master studies in BIS and their level of professional skills acquired. We conclude that between the two groups are not only important similarities regarding key satisfaction factors but also some differences regarding their future options that could be justified as the two regions in Romania offer different business opportunities for BIS students.
\end{abstract}

Keywords: academic/bachelor program, Business Information Systems specialization, satisfaction factors, students' satisfaction.

JEL classification: J24, I21, I23

DOI: $10.24818 / \mathrm{ie} 2020.02 .10$

\section{Introduction and theoretical background}

In the field of business, satisfaction is frequently measured but in recent times, educational institutions became also interested in determining the level of satisfaction. Many authors nowadays agree with O'Donovan: "student satisfaction matters, and arguably matters more than ever within an increasingly competitive higher education sector" [1]. These days we witness not only the competition between universities for good students in times of birth rate decrease with declining enrolment but also their interest to "improve the likelihood of students' persistence in their studies" [2] [3]. For any university, different issues are used in attracting new students and retaining students, but we say that the perceived quality of the academic programs is useful for both scopes. In recent years, we have witnessed decentralization in publicity and promotion of academic programs: many actions are organized or supervised by academic departments and not by faculty or university. The study we have carried out provides our departments with relevant information about students' satisfaction with BIS specialization. 
Evaluating third-year students gives a helpful representation of their satisfaction with the academic program, knowing that their opinion may also lead to attracting new students for BIS specialization.

Undoubtedly, for a student, it is very important to be satisfied with his study line or chosen specialization, like it is for an employee to be satisfied with his job. However, a large number of studies addressed employees' satisfaction with their jobs, but a smaller amount of research studies addressed students' satisfaction with their academic studies. More frequently found in the literature were the papers analyzing persistence/dropout of academic studies.

Notable contributions in this field were found in many papers from the 80s and 90s. First, we have Sevier's argument that "a university's product is not academic programs, but a sum of the student's academic, social, and spiritual experiences" [4]. However, this research domain has considered having only "few theoretical underpinnings" [5]. The most arguable issue is the definition of the construct [5] with many different aspects involved: cognitive aspects [7], affective aspects [6], or attitude-related aspects [8]. Other researchers argued the importance of students' satisfaction investigation in relation to academic achievement $[9,10]$.

We also have the similitude with customer satisfaction, based on the paper of Peterson and Wilson, which states, "Virtually all company activities, programs, and policies should be evaluated in terms of their contribution to satisfying customers" [11]. Therefore, many marketing researchers investigate students' satisfaction. However, for our case study, the customer-oriented approach is only partially fitted because most of the students we have considered do not have to pay for their studies.

The literature review of students' satisfaction description revealed many viewpoints. A significant number of papers were found in the services and consumer marketing literature, where "satisfaction is defined as pleasurable fulfilment" and "the consumer's sense that consumption provides outcomes against a standard of pleasure versus displeasure." [12]

We have found one very good representation of the concept at Oliver and DeSarbo; their definition of student satisfaction as "the favorability of a student's subjective evaluation of the various outcomes and experiences associated with education" [13] is mentioned in many papers. In a similar interpretation, Elliot and Healy define student satisfaction as "a short-term attitude that results from the evaluation of their experience with the education service received" [14], while Marzo-Navarro et al relate students' satisfaction with "the intention to recommend the courses to others." [15]

Allen affirmed that for a student, satisfaction with his field of study is equivalent to job satisfaction because, "like work environments, academic environments vary with respect to [...] opportunities to use various skills and interests and to implement his self-concept." [16] We also agree with the idea that student's satisfaction with his field of study "has potential as a proxy for later job satisfaction" [17] because of the investigated field of study, in our case, the Business Information Systems program.

Many reviewed papers by Sim [18] stressed the idea that students' satisfaction concept has a multi-dimensional nature. Not having a commonly accepted definition and lacking a recognized theoretical framework, the measuring of students' satisfaction takes multiple forms; some say that "there are almost as many different measures of satisfaction reported as there are studies investigating the construct" [2]. This idea frankly reveals the large variety of studies, from classical like Morstain's "analysis of students' satisfaction with their academic program" [19], to a plethora of research studies after 2000. We further describe a few representative studies, which have motivated our research.

The theories on university dropout from the 80 s and 90 s identified poor academic performance and lack of social integration as the most significant factors; afterwards, more attention was paid to the possible impact of students' satisfaction with the chosen academic program [20]. 
www.conferenceie.ase.ro

Many studies are constructed around the idea that the student may be seen as a customer and addressed the relationship between perceptions of service quality and students' satisfaction (e.g. [21]).

A comprehensive student satisfaction survey has a multidimensional structure. For example, a study-satisfaction questionnaire used in Norwegian universities analyses three dimensions: study content ("the feelings of joy and satisfaction" regarding chosen specialization), environment ("the terms and conditions of the academic program"), and student's "ability to cope with academic stress." [22] Nevertheless, as their analysis reveals, "the academic and pedagogic quality of teaching are crucial determinants of student satisfaction" and this conclusion underpins the approach of our analysis. Alves and Raposa proposed a very solid conceptual model of student's satisfaction, by testing an explanatory model in Portugal universities; they determined that "the main consequence of satisfaction was student loyalty caused by word of mouth from student to student." [23]

An academic program satisfaction study was conducted in a Dutch university in relation to "the fulfilment of expectations regarding the content of the degree program and the required study activities" [20]. However, this study targeted students in their first- and second years of study and was focused on their dropout.

As a final point of our literature review, we learned numerous possible angles on the satisfaction concept due to its many facets (the quality of teaching or advising, the quality of different services, the quality of social life, etc.) and understood that research methods differ in the framework of purposes and magnitude of the studies. Differences also come forward due to the category of students: many studies target first- and second-year students, others terminal year or master enrolled students, or entail the alumni opinions. There are many studies at a national level, at university or institution level, but fewer at the degree program level; moreover, we did not meet a students' satisfaction comparative study for one program in different faculties.

The students' satisfaction may be investigated with reference to its many facets, but also about the overall choice. Our study intended to investigate the students' global satisfaction with the chosen specialization, trying to determine the key predictors of an academic program satisfaction.

\section{Research methodology}

Due to the space limitation, we choose to include in the current paper only one research question $(\boldsymbol{R Q})$, namely

RQ: Are there differences between how the students from Iaşi (IS) and those from Timişoara (TM) are satisfied with the BIS specialization and their options for their future education (i.e. continuing to master in BIS)?

The current research has a comparative approach and is based on quantitative methods. To find answers for our RQ, we proposed three working hypotheses:

H1: The main factors driving students' satisfaction with their study program do not differ between IS and TM.

H2: There is a significant relationship between students' satisfaction and their rating on their professional skills.

H3: There is a significant relationship between students' satisfaction and their intention to go on with a BIS master program.

The research model (Figure 1) is based on DesShields\&Kara\&Kaynak model [24], which combines Tinto's model [25] and SSRM model of Keaveney \&Young [26]. This model was confirmed by Helgesen \& Nesset [27], Gruber et al. [28] and Tsinidou et al. [29]. 
An important component of the current research is data collection, which was based on the questionnaire technique. The research instrument, containing 68 questions, covers many aspects regarding the profile of BIS students and their opinions about the program, but for this study, we selected only six grid questions with five grades of acceptance. The questionnaire was designed to measure the constructs displayed in Figure 1. The questions (Q1, Q2, Q4, Q6_1 - Q6_8) asked participants to rate how strongly they agreed with each statement using 5 Likert scale, while Q3 and Q6_2 asked about the future desire of continuing their master studies in BIS and their level on professional skills acquired.

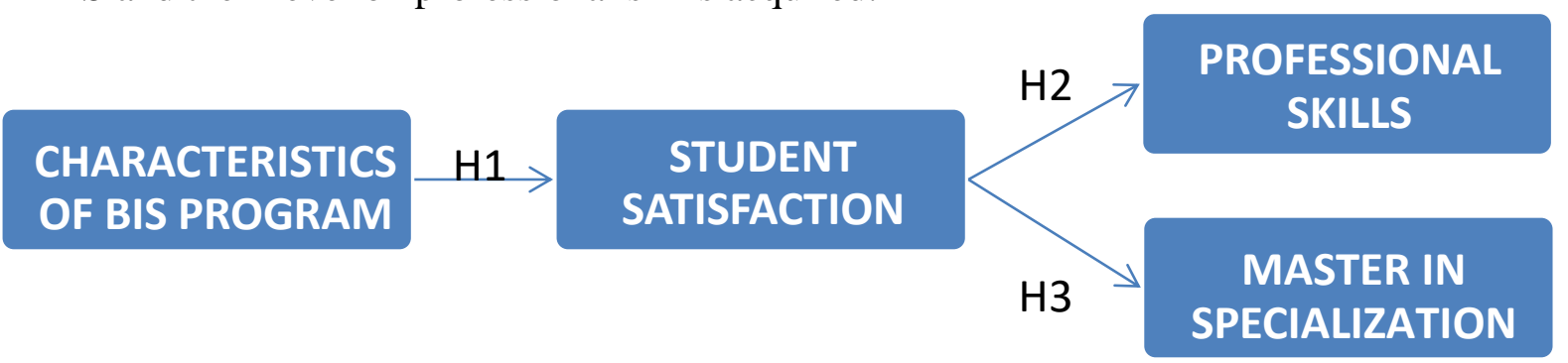

Figure 1. The research model

The questionnaire was distributed for 5 years in a row between 2016 and 2020 to all the BIS third-year students in IS and TM. The total number of students from IS is double those of TM and the rejection rate was similar for both (around 30\%). After validation, the sample includes 740 subjects. Among the 740 respondents, 458 were from Iaşi (female $65.7 \%$ and male $34.3 \%$ ) and 282 from Timişoara (female 51.8\% and male 48.2\%).

Data management and analysis were performed using SPSS software. As the majority of questions are Likert scale type, the reliability of the instrument was calculated using Cronbach's alpha. For our research, the resulting value is $\mathbf{0 . 9 0 7 , ~ w h i c h ~ i n d i c a t e s ~ a ~ h i g h ~ l e v e l ~}$ of internal consistency for our scale with this specific sample.

Descriptive data were generated for all variables and the significance levels were set at the 0.05 level using the Chi-Square test. The answers were analyzed by descriptive statistics with SPSS using frequency analysis, descriptive indicators of central tendency, quartiles and dispersion indicators and non-parametric tests for hypothesis validation.

\section{Findings and discussion}

The first hypothesis targets the hierarchy of the students' satisfaction factors (H1) in order to highlight differences between the two groups (IS and TM). For evaluating students' satisfaction, respondents were asked to grade a list of factors in terms of their importance using questions like "Why am I satisfied with pursuing the BIS program?" and "I like BIS undergraduate program because..." As presented in Table 1, students' opinions are similar to an extent and different at the same time, for the two analyzed groups. The similarity is met in the top three answers and the differences in their order.

While IS students assign the highest importance to the teamwork features, students from Timişoara rank highest the seriousness features. Furthermore, the analysis of the mean values shows that students from IS manifest more enthusiasm compared to those from TM. Consequently, they disclose in many questions a tendency to selecting higher values (close to 5) compared with the TM group. In contrast, TM students have, in all cases, higher values for Std. deviation. Thus, their answers are spread out over a wider range while the answers of the IS group tend to be closer to the mean.

Based on these results, we may conclude that hypothesis $\mathrm{H} 1$ is partially validated because of the similar top three factors and the presence of the same nine (out of ten) factors in the ranking. 
www.conferenceie.ase.ro

Table 1. Top 10 satisfaction factors ranked in a comparative analysis

\begin{tabular}{|l|c|c|c|l|c|c|c|}
\hline \multicolumn{1}{|c|}{ BIS-IS } & Rank & Mean & $\begin{array}{c}\text { Std. } \\
\text { Dev }\end{array}$ & \multicolumn{1}{|c|}{ BIS-TM } & Rank & Mean & $\begin{array}{c}\text { Std. } \\
\text { Dev }\end{array}$ \\
\hline Promotes teamwork & 1 & 4,493 &, 6768 & $\begin{array}{l}\text { Demands seriousness } \\
\text { from its students }\end{array}$ & 1 & 3,830 &, 9044 \\
\hline $\begin{array}{l}\text { Demands seriousness } \\
\text { from its students }\end{array}$ & 2 & 4,343 &, 7231 & $\begin{array}{l}\text { Provides a competitive } \\
\text { environment for students }\end{array}$ & 2 & 3,674 & 1,023 \\
\hline $\begin{array}{l}\text { Provides a competitive } \\
\text { environment for students }\end{array}$ & 3 & 4,266 &, 7833 & Promotes teamwork & 3 & 3,663 & 1,003 \\
\hline $\begin{array}{l}\text { Offers professional and } \\
\text { life models through its } \\
\text { professors }\end{array}$ & 4 & 4,115 &, 8138 & $\begin{array}{l}\text { Has good reputation both } \\
\text { in the academic and } \\
\text { business environment }\end{array}$ & 4 & 3,589 &, 8814 \\
\hline $\begin{array}{l}\text { Cultivate the pride of } \\
\text { being a student of this } \\
\text { program }\end{array}$ & 5 & 4,020 &, 9373 & $\begin{array}{l}\text { Changed me in a positive } \\
\text { way }\end{array}$ & 5 & 3,528 &, 9734 \\
\hline $\begin{array}{l}\text { Creates an environment } \\
\text { where professors } \\
\text { communicate very well } \\
\text { with students }\end{array}$ & 6 & 3,998 &, 8169 & $\begin{array}{l}\text { Offers professional and } \\
\text { life models through its } \\
\text { professors }\end{array}$ & 6 & 3,518 &, 9700 \\
\hline $\begin{array}{l}\text { Changed me in a positive } \\
\text { way }\end{array}$ & 7 & 3,956 &, 9041 & $\begin{array}{l}\text { Creates an environment } \\
\text { professors communicate } \\
\text { very well with students }\end{array}$ & 7 & 3,511 &, 9056 \\
\hline $\begin{array}{l}\text { Provides education with } \\
\text { unique attributes that are } \\
\text { required by IT firms }\end{array}$ & 8 & 3,881 &, 8186 & $\begin{array}{l}\text { Provides education with } \\
\text { unique attributes that are } \\
\text { required by IT firms }\end{array}$ & 8 & 3,443 &, 9387 \\
\hline $\begin{array}{l}\text { Has good reputation both } \\
\text { in the academic and } \\
\text { business environment }\end{array}$ & 9 & 3,855 &, 8920 & $\begin{array}{l}\text { Cultivate the pride of } \\
\text { being a student of this } \\
\text { program }\end{array}$ & 9 & 3,394 & 1,015 \\
\hline $\begin{array}{l}\text { Compared to other } \\
\text { programs, BIS is } \\
\text { conducive to study }\end{array}$ & 10 & 3,746 &, 9272 & $\begin{array}{l}\text { Ensures high-quality } \\
\text { education for students at } \\
\text { a low fee (or no fee) }\end{array}$ & 10 & 3,369 &, 9350 \\
\hline
\end{tabular}

Further, data analysis for testing hypothesis $\mathrm{H} 2$ and $\mathrm{H} 3$ is displayed in Table 2 (BIS-IS and BIS-TM students satisfaction factors vs Q1 and Q2).

The Chi-square test was applied to analyze the relation between the variables Q6_1 - Q6_8 and the factors Q1 and Q2, for each of the two groups. The results (Table 2) highlight that in all cases, except Q6_5 vs Q1 (for IS) and Q6_5 vs Q2 (for TM) there are significant differences (marked with *) in the perception of the two groups towards their satisfaction with the BIS program. As such, the following characteristics can be depicted:

1. The comparative analysis of satisfaction factors and professional skills level shows that the majority of students with a good and satisfactory level of professional skills:

a) rank six of the satisfaction factors (Q6_2, Q6_4 - Q6_8) with the fourth and fifth-highest scores (BIS-IS) and, respectively, with the third and fourth highest scores (BIS-TM). As such, TM respondents are manifesting a reluctance to awarding the highest score - as a sign that these six factors are not as important as they are for the IS students;

b) rank Q6_1 satisfaction factor with the same scores, namely with the fourth and fifth-highest values. Therefore, while the IS students remain consequent with the previous six cases (case a), the TM students shift forward one value and award the fourth and fifth-highest scores as a sign of a higher valuation for this factor compared with case a);

c) rank Q6_3 satisfaction factor with the same scores, namely with the third and fourth-highest scores. Thus, while the TM students remain consistent with the previous case a), the IS 
students shift backwards one rating and award the third and fourth-highest scores displaying lower importance for this factor for IS students compared with cases a) and $b$ ).

Table 2. The analysis of BIS program satisfaction vs professional skills rating (Q1) and master pursuing within a BIS program (Q2)

\begin{tabular}{|c|c|c|c|c|c|}
\hline \multirow{2}{*}{\multicolumn{2}{|c|}{$\begin{array}{l}\text { Q6 - I am satisfied with Business Information } \\
\text { Systems program because: }\end{array}$}} & \multicolumn{2}{|c|}{ Iaşi (IS) } & \multicolumn{2}{|c|}{ Timişoara (TM) } \\
\hline & & Q1 & Q2 & Q1 & Q2 \\
\hline \multirow{2}{*}{$\begin{array}{l}\text { Q6_1 } \\
\text { Provides opportunities for an effective } \\
\text { career start }\end{array}$} & \multirow{2}{*}{$\begin{array}{l}\text { Chi-square } \\
\text { df } \\
\text { Sig. }\end{array}$} & $\begin{array}{l}83,834 \\
16\end{array}$ & $\begin{array}{l}35,884 \\
16\end{array}$ & $\begin{array}{l}28,302 \\
16\end{array}$ & $\begin{array}{l}30,256 \\
16\end{array}$ \\
\hline & &, 000 & & & 017 \\
\hline \multirow{2}{*}{$\begin{array}{l}\text { Q6_2 } \\
\text { Provides education with unique } \\
\text { attributes that are required by IT firms }\end{array}$} & \multirow{2}{*}{$\begin{array}{l}\text { Chi-square } \\
\text { df } \\
\text { Sig. }\end{array}$} & $\begin{array}{l}60,746 \\
16\end{array}$ & $\begin{array}{l}45,282 \\
16\end{array}$ & $\begin{array}{l}64,661 \\
16\end{array}$ & $\begin{array}{l}35,320 \\
16\end{array}$ \\
\hline & &, 000 & & & , 00 \\
\hline \multirow{2}{*}{$\begin{array}{l}\text { Q6_3 } \\
\text { Provides a competitive environment for } \\
\text { students compared to other } \\
\text { specializations }\end{array}$} & \multirow{2}{*}{$\begin{array}{l}\text { Chi-square } \\
\text { df } \\
\text { Sig. }\end{array}$} & $\begin{array}{l}34,720 \\
16\end{array}$ & $\begin{array}{l}36,499 \\
16\end{array}$ & $\begin{array}{l}45,970 \\
16\end{array}$ & $\begin{array}{l}36,857 \\
16 \\
\end{array}$ \\
\hline & & ,004 & & &, $002 *$ \\
\hline & \multirow{2}{*}{$\begin{array}{l}\text { Chi-square } \\
\text { df } \\
\text { Sig. }\end{array}$} & $\begin{array}{l}47,075 \\
16\end{array}$ & $\begin{array}{l}61,017 \\
16\end{array}$ & $\begin{array}{l}47,211 \\
16\end{array}$ & $\begin{array}{l}42,355 \\
16\end{array}$ \\
\hline & &, 00 &, 00 &, 00 &, $000^{*}$ \\
\hline \multirow{2}{*}{$\begin{array}{l}\text { Q6_5 } \\
\text { Ensures very good communication } \\
\text { with professors }\end{array}$} & \multirow{2}{*}{$\begin{array}{l}\text { Chi-square } \\
\text { df } \\
\text { Sig. }\end{array}$} & $\begin{array}{l}8,973 \\
6\end{array}$ & $\begin{array}{l}54,759 \\
16\end{array}$ & $\begin{array}{l}50,919 \\
16\end{array}$ & $\begin{array}{l}23,395 \\
16\end{array}$ \\
\hline & & & & & 0,10 \\
\hline \multirow{2}{*}{$\begin{array}{l}\text { Q6_6 } \\
\text { Has a very good reputation both in the } \\
\text { academic and business environment }\end{array}$} & \multirow{2}{*}{$\begin{array}{l}\text { Chi-square } \\
\text { df } \\
\text { Sig. }\end{array}$} & $\begin{array}{l}19,529 \\
16\end{array}$ & $\begin{array}{l}37,067 \\
16\end{array}$ & $\begin{array}{l}31,205 \\
16\end{array}$ & $\begin{array}{l}30,993 \\
16 \\
\end{array}$ \\
\hline & &, 00 &, 00 & 01 &, $013^{*}$ \\
\hline \multirow{2}{*}{$\begin{array}{l}\text { Q6_7 } \\
\text { Cultivates the pride of being a student } \\
\text { of this program }\end{array}$} & \multirow{2}{*}{$\begin{array}{l}\text { Chi-square } \\
\text { df } \\
\text { Sig. }\end{array}$} & $\begin{array}{l}28,264 \\
16\end{array}$ & $\begin{array}{l}42,315 \\
16\end{array}$ & $\begin{array}{l}45,322 \\
16\end{array}$ & $\begin{array}{l}36,374 \\
16\end{array}$ \\
\hline & &, 02 &, 000 &, 000 &, $003 *$ \\
\hline \multirow{2}{*}{$\begin{array}{l}\text { Q6_8 } \\
\text { Offers professional and life models } \\
\text { through its professors }\end{array}$} & \multirow{2}{*}{$\begin{array}{l}\text { Chi-square } \\
\text { df } \\
\text { Sig. }\end{array}$} & $\begin{array}{l}57,095 \\
16\end{array}$ & $\begin{array}{l}53,571 \\
16\end{array}$ & $\begin{array}{l}27,785 \\
16\end{array}$ & $\begin{array}{l}47,011 \\
16\end{array}$ \\
\hline & &, $000 *$ & ,000* & ,034* & $000^{*}$ \\
\hline
\end{tabular}

* The Chi-square statistic is significant at the 0.05 level.

2. The comparative analysis of satisfaction factors in relation with the intention to continue studying within the BIS specialization identifies the following patterns for the majority of students that ,wish” or ,with certainty” will pursue a BIS master program:

a) the IS group award in seven cases (Q6_1 - Q6_2, Q6_4 - Q6_8) the fourth and fifth-highest values for the above-mentioned satisfaction factors. The differences among the IS group is the maximum share given. Thus, in case of Q6_3, the highest share of students shift backwards one point and award third and fourth highest values for this satisfaction factor - showing that it is the least important among the eight factors.

b) the TM group (compared with IS) give in all eight cases one point backwards on the 5 Likert scale, namely the third and fourth-highest values for these satisfaction factors. The only difference among the TM group are the maximum share given. Compared with IS, these eight factors do not have the same importance for TM.

In the light of the above information, as the significance value of the Chi-squared test is less than 0.05 (see Table 2), we can affirm, with a 5\% risk, that there are differences between the two groups regarding their satisfaction towards BIS program in relation with the respondents' 
professional skills rating (Q1) and their intention to continue their studies within BIS master program (Q2). Consequently, hypotheses $\mathrm{H} 2$ and $\mathrm{H} 3$ are validated.

\section{Conclusion, limitations and further research}

The survey revealed that students are satisfied with their study program and there are similarities in the key predictors of their satisfaction in the two considered groups. However, there were disparities in the factors' scoring. The general conclusion is that BIS-IS group act homogenously and tend to easily award the highest grade (5), while BIS-TM group act heterogeneously and tend to be more prudent when awarding scores, being more on the "neutral" and "thinking about it" side of the matter. This disparity in the two groups could be justified as the two regions in Romania offer different opportunities for BIS students. While in Iaşi the IT sector is predominant and tends to have a monopoly over the younger generation's careers, in Timişoara the BIS students are also given opportunities from outside of the IT sector. During this study, several limitations arise. One limitation comes from the personal bias of the researchers based on their professional experience. Researchers made every attempt to remain impartial in presenting data and to provide a balanced perspective throughout.

Due to the limited number of pages, the empirical research in this article does not cover a longitudinal research approach. Thus, another limitation could rise because it was not possible to conclude that all the results regarding students' satisfaction are stable or not.

The third limitation refers to the number of universities involved in the research. As the study investigates only two samples of students from two universities, the results cannot be generalized to the Romanian student population as a whole. The research could be extended in the future to other universities having BIS specialization in their educational offer. Cultural differences could also be taken into consideration.

Our future work will be oriented to solve the above limitations and to extend the research in three dimensions: depending the present research (developing the research model by adding new items, clarifying some questions etc.), longitudinal approach and national cover.

The influence of the demographic variables (gender, background specialization and some character traits) on our research objectives will be analyzed in future research. We also intend to take a longitudinal approach in the future to see if the results suffer changes over time, especially due to the shift from Gen $Y$ to Gen $X$ during the analyzed period.

\section{References}

[1] B. O'Donovan, "How student beliefs about knowledge and knowing influence their satisfaction with assessment and feedback," Higher Education, vol.74, pp.617-633, 2017.

[2] F. Wach, J. Karbach, S.Ruffing, R. Brünken and F.M. Spinath, "University Students' Satisfaction with their Academic Studies: Personality and Motivation Matter," Frontiers in Psychology, pp. 7:55, 2016.

[3] K.M. Elliott and D. Shin, "Student satisfaction: an alternative approach to assessing this important concept," Journal of Higher Education Policy Management, vol.24, pp. 199-209, 2002.

[4] R.A. Sevier, "Those Important Things: What Every College President Needs to Know about Marketing and Student Recruiting," College \& University, pp. 9-16, Spring 1996.

[5] M. Benjamin and A. Hollings, "Student satisfaction: test of an ecological model," Journal of College Student Development vol. 38, no. 3, pp. 213-228, 1997.

[6] J.P. Bean, and R.K. Bradley, "Untangling the satisfaction-performance relationship for college students," The Journal of Higher Education, vol. 57, no.3, pp. 393-412, Nov. 1986.

[7] M.A. Okun, and R.M. Weir, "Toward a judgement model of college satisfaction," Educational Psychology Review, vol. 2, no. 1, pp. 59-76, March 1990. 
[8] J.G. Reed, M.A. Lahey and R.G. Downey, "Development of the college descriptive index: a measure of student satisfaction," Measurement and Evaluation in Counseling and Development. vol.17, no. 2, pp. 67-82, 1984.

[9] S.S. Graunke, \& S.A. Woosley, "An exploration of the factors that affect the academic success of college sophomores," College Student Journal, vol. 39, pp. 367-376, 2005.

[10] H. Kim, and O. Kim, "Factors Affecting Major Satisfaction of College Students," Advanced Science and Technology Letters, vol.133, pp.50-56, 2016, Proc. of Conference: Information Technology and Computer Science, 2016.

[11] R.A. Peterson and W.R. Wilson, "Measuring Customer Satisfaction: Fact and Artifact," Journal of the Academy of Marketing Science, vol. 20, no. 1, pp. 61-71, 1992.

[12] R.L. Oliver, "Whence consumer loyalty," Journal of Marketing, vol. 63, pp. 33-44, 1999.

[13] R.L. Oliver and W.S. DeSarbo, "Processing of the satisfaction response in consumption: A suggested framework and research proposition," Journal of Consumer Satisfaction, Dissatisfaction and Complaining Behavior, vol. 2, pp. 1-16, 1989.

[14] K.M. Elliott and M.A. Healy, "Key factors influencing student satisfaction related to recruitment and retention," Journal of Marketing for Higher Education, vol. 10, no. 4, pp. $1-11,2001$.

[15] M. Marzo-Navarro, M. Pedraja-Iglesias and P. Rivera-Torres, "A new management element for universities: satisfaction with the offered courses," International Journal of Educational Management, vol. 19, no. 6, pp. 505-526, 2005.

[16] M. L. Allen, "Dimensions of educational satisfaction and academic achievement among music therapy majors," Journal of Music Therapy, vol. 33, pp. 147-160, 1996.

[17] M. Nauta, "Assessing College Students' Satisfaction with their Academic Majors," Journal of Career Assessment, vol. 15, no. 4, pp. 446-462, 2007.

[18] L.L. Sim, "Determinants of Students' Satisfaction and Students' Loyalty in College X: A Case Study," MBA Dissertation Malaysia, 2008, Available at: http://eprints.usm.my/25366/1/ determinants_of_students\%e2\%80\%99_satisfaction.pdf

[19] B.R. Morstain, "An Analysis of Students' Satisfaction with Their Academic Program," The Journal of Higher Education, Volume 48 / Issue 1, pp. 1-16, 1977.

[20] C. Suhre, E. Jansen and E. Harskamp, "Impact of degree program satisfaction on the persistence of college students," Higher Education, vol. 54, pp. 207-226, 2007.

[21] C. Munteanu et al. "An analysis of customer satisfaction in a higher education context," International Journal of Public Sector Management, vol. 23, pp. 124-140, 2010.

[22] J. Wiers-Jenssen, B. Stensaker, J. Grøgaard, "Student satisfaction: towards an empirical deconstruction of the concept," Quality in Higher Education, vol. 8, pp. 183-195, 2002.

[23] Alves, H. and Raposa, M. "Conceptual Model of Student Satisfaction in Higher Education," Total Quality Management, vol. 17, no. 9, pp. 1261-1278, 2006.

[24] O.W. Jr. DeShields, A. Kara, and E. Kaynak, "Determinants of business student satisfaction and retention in higher education: applying Herzberg's two-factor theory," International Journal of Educational Management, vol. 19, no. 2, pp. 128-39, 2005.

[25] V. Tinto, "Leaving college: Rethinking the causes and cures of student attrition," Chicago: University of Chicago Press, 1987.

[26] S.M. Keaveney and C.E. Young, "The Student Satisfaction and Retention Model (SSRM)," Graduate School of Business Administration: University of Colorado, 1997.

[27] Ø. Helgesen, E. Nesset, "What accounts for students' Loyalty? Some field study evidence," International Journal of Educational Management, vol.21, no.2, pp.126-143, 2007. 
www.conferenceie.ase.ro

[28] T. Gruber, S. Fuß, R. Voss and M. Glaeser-Zikuda. "Examining student satisfaction with higher education services: Using a new measurement tool," International Journal of Public Sector Management, vol. 23, no.2, pp.105-123, 2010.

[29] M. Tsinidou, G. Vassilis and F, Panos, "Evaluation of the factors that determine quality in higher education: an empirical study," Quality assurance in Education, vol. 18, no. 3, pp. 227-244, 2010. 